\title{
O céu se rasga, rasga-se o véu do templo A nova proposta religiosa de Jesus
}

\author{
Orientador: Prof. Geraldo Dondici Vieira \\ Pesquisadora: Lídia Maria Carneiro de Resende \\ Projeto de Pesquisa: Literatura Apócrifa Judaica e a Interpretação do Novo \\ Testamento
}

Fonte: $\mathrm{CNPq}$

O presente projeto de estudo e pesquisa, com base e $M c$ 1,10 e 15,38 refletiu sobre uma das chaves de leitura deste Evangelho e o enriquecimento com um assunto pouco explorado pela Exegese. Favorecendo o crescimento da divulgação da Boa Nova hoje e apresentando uma possível inclusão do verbo "rasgar", presente nas duas perícopes. A importância desses estudos está nas diferentes possibilidades de abordagem que facilitam a compreensão e abrem novos caminhos para a hermenêutica.

A pesquisa visava demonstrar que o movimento de "rasgar" é uma chave de leitura que abre e fecha $M c$, um simbolismo que ajuda a compreender a proposta religiosa de Jesus nesse Evangelho. Aprofundando uma das chaves de leitura do Evangelho que é a da inclusão. 